\title{
Detection of virulence and multidrug resistance operons in Pseudomonas aeruginosa isolated from Egyptian Baladi sheep and goat
}

\author{
A. N. Dapgh ${ }^{1}$, A. S. Hakim², H. A. Abouelhag', A. M. Abdou² and E. A. Elgabry²
}

1. Department of Bacteriology, Animal Health Research Institute, Dokki, Giza, Egypt; 2. Department of Microbiology and Immunology, National Research Centre, 33 Bohouth Street, 12622 Dokki, Cairo, Egypt.

Corresponding author: A. S. Hakim, e-mail: migris410@yahoo.com

Co-authors: AND: amanydapgh@yahoo.com, HAA: drabouelhag@yahoo.com, AMA: amrkheir@yahoo.com, EAE: elgabry7373@yahoo.com

Received: 07-05-2019, Accepted: 26-08-2019, Published online: 04-10-2019

doi: 10.14202/vetworld.2019.1524-1528 How to cite this article: Dapgh AN, Hakim AS, Abouelhag HA, Abdou AM, Elgabry EA (2019) Detection of virulence and multidrug resistance operons in Pseudomonas aeruginosa isolated from Egyptian Baladi sheep and goat, Veterinary World, 12(10): 1524-1528.

\begin{abstract}
Background: Pseudomonas aeruginosa is a pit of an enormous group of free-living bacteria that are able to live everywhere and suggested to be the causative agent of great scope of acute and chronic animal infections.
\end{abstract}

Aim: The current study was carried out to illustrate the prevalence of $P$. aeruginosa in small ruminants and existence of some virulence operons as well as its antimicrobial resistance.

Materials and Methods: A total of 155 samples from sheep and 105 samples from goats (mouth abscesses, fecal swabs, nasal, tracheal swabs, and lung tissue) were collected for bacteriological study, existence of some virulence expression operons with the study of their sensitivity to the antimicrobials using disc diffusion and presence of mexR operon which is responsible for multidrug resistance (MDR).

Results: The bacteriological examination revealed that $P$. aeruginosa was isolated from nine out of 155 samples from sheep $(5.8 \%)$ and four isolates out of 105 samples from goat (3.8\%). It is found that $12(92.3 \%), 10(76.9 \%)$, and $8(61.5 \%)$ of $P$. aeruginosa isolates harbored hemolysin phospholipase gene $(p c l \mathrm{H})$, gene $(\operatorname{exoS})$, and enterotoxin gene $($ tox $\mathrm{A})$, respectively. The results of antibiotic sensitivity test showed that all tested isolates were resistant to ampicillin, bacitracin, erythromycin, streptomycin, tetracycline, trimethoprim-sulfamethoxazole, and tobramycin but sensitive to ciprofloxacin and norfloxacin. The MDR (mexR) operon was existed in all isolates.

Conclusion: There is a growing risk for isolation of virulent MDR P. aeruginosa from sheep and goat illness cases, and this should be regarded in the efficient control programs.

Keywords: drug resistance, goat, Pseudomonas aeruginosa, sheep, virulence.

\section{Introduction}

Pseudomonas aeruginosa is a Gram-negative, encapsulated, nonsporulated, and strict aerobic motile rod. It is an opportunistic pathogen, widely exists in various ecosystems and believed to be implemented in several serious human and animal diseases [1,2]. $P$. aeruginosa causes numerous diseases in sheep and goats; respiratory illness, which is one of the major issues particularly pneumonia, associated with physical and physiological stress, leading to significant mortality rates, and increased economic loss [3]. A number of mastitis cases and the pathogen can reside in the udder for many years [4]. Moreover, $P$. aeruginosa infection may lead to urogenital disorders, gastrointestinal illness sinusitis, and osteomyelitis [5-8].

The organism declares plenty of virulence agents, which share in its pathogenicity. These comprise

Copyright: Dapgh, et al. Open Access. This article is distributed under the terms of the Creative Commons Attribution 4.0 International License (http://creativecommons.org/licenses/by/4.0/), which permits unrestricted use, distribution, and reproduction in any medium, provided you give appropriate credit to the original author(s) and the source, provide a link to the Creative Commons license, and indicate if changes were made. The Creative Commons Public Domain Dedication waiver (http://creativecommons.org/ publicdomain/zero/1.0/) applies to the data made available in this article, unless otherwise stated. enterotoxins, exocytotoxins, and toxins produced by protein secretion systems, as a result of expression of certain virulence operons. Consequently, many of these have been implemented in infection, septicemia, and fatal condition $[9,10]$. The mortality rate is usually higher than bacteremia sourced with other Gram-negative pathogens due to its ability to secrete these several products that after successive colonization can induce extensive tissue damage, bloodstream invasion, and dissemination [11]. Through all resistant pathogens, the condition is most significant for $P$. aeruginosa as its incidence of resistance to antimicrobial agents in continuous increasing and has been accounted worldwide [12]. This critical ability of the pathogen could be attributed to the existence of the unusually restricted outer membrane permeability which acts as a safeguard barrier for antibiotics to overcome. Besides that, there were other secondary intrinsic factors as energy-dependent multidrug efflux and chromosomally encoded periplasmic beta-lactamase [13].

This study was conducted to address its isolation and identification from ovine and caprine population, with stressing on its toxigenic expressed operons as well as the associated multidrug resistance (MDR) property. 


\section{Materials and Methods}

\section{Ethical approval}

As per CPCSEA guidelines, a study involving clinical samples does not require the approval of the Institute Animal Ethics Committee.

\section{Samples}

A total of 260 different samples were collected from sheep (155) and from goat (105) selectively suffering from respiratory manifestation (40 from sheep, and 22 from goats) in triplicate as nasal, tracheal swabs, and lung tissues. Also, fecal samples were collected from diarrheic (14 sheep and 23 goats) and gathered swabs from skin lesion with abscesses (21 sheep and 16 goats). The samples were gathered from scattered local farms or owners in Great Cairo and Delta rural areas. The samples were gathered from September 2017 to April 2018. The samples were bacteriologically examined and the selected colonies were biochemically identified [14].

\section{Antimicrobial sensitivity assay}

The susceptibility of the isolates to various antibiotics was achieved using the diffusion technique [15], the following antibiotic discs were used; amikacin (30 mg), ampicillin (10 $\mu \mathrm{g})$, bacitracin (10 $\mu \mathrm{g})$, chloramphenicol (30 $\mu \mathrm{g})$, erythromycin $(15 \mu \mathrm{g})$, gentamycin $(10 \mu \mathrm{g})$, streptomycin $(10 \mu \mathrm{g})$, tetracycline $(30 \mu \mathrm{g})$, trimethoprim-sulfamethoxazole
$(2.25 / 7.75 \mu \mathrm{g})$, tobramycin $(30 \mu \mathrm{g})$, ciprofloxacin $(5 \mu \mathrm{g})$, and norfloxacin $(10 \mu \mathrm{g})$ [16].

\section{DNA extraction}

DNA extraction from the samples was performed using the QIAamp DNA Mini kit (Qiagen, Germany, $\mathrm{GmbH}$ ) with modifications from the manufacturer's recommendations. Briefly, $200 \mu \mathrm{l}$ of the sample suspension was incubated with $10 \mu \mathrm{l}$ of proteinase $\mathrm{K}$ and $200 \mu \mathrm{l}$ of lysis buffer at $56^{\circ} \mathrm{C}$ for $10 \mathrm{~min}$. After incubation, $200 \mu \mathrm{l}$ of $100 \%$ ethanol was added to the lysate. The sample was then washed and centrifuged following the manufacturer's recommendations. Nucleic acid was eluted with $100 \mu \mathrm{l}$ of elution buffer provided in the kit.

\section{Polymerase chain reaction (PCR) amplification using oligonucleotide primers}

Primers used were supplied from Metabion (Germany), as shown in Tables-1 and 2 [16,17]. Primers were utilized in a $25 \mu \mathrm{l}$ reaction containing $12.5 \mu \mathrm{l}$ of Emerald Amp Max PCR Master Mix (Takara, Japan), $1 \mu \mathrm{l}$ of each primer of $20 \mathrm{pmol}$ concentrations, $4.5 \mu \mathrm{l}$ of water, and $6 \mu \mathrm{l}$ of DNA template. The reactions were performed either uniplex (mexR) or multiplex (exoS, pcl $\mathrm{H}$, and tox $\mathrm{A}$ ), as described in Tables-1 and $2[17,18]$, in a T3 Biometra thermal cycler.

\section{Analysis of the PCR products}

The products of PCR were electrophoresed on $1.5 \%$ agarose gel (Applichem, Germany, $\mathrm{GmbH}$ ) in

Table-1: Uniplex PCR: Primers sequences, target operons, amplicon sizes, and cycling conditions.

\begin{tabular}{|c|c|c|c|c|c|c|c|c|}
\hline \multirow{2}{*}{$\begin{array}{l}\text { Target } \\
\text { operon }\end{array}$} & \multirow{2}{*}{$\begin{array}{l}\text { Primers } \\
\text { sequences }\end{array}$} & \multirow{2}{*}{$\begin{array}{c}\text { Amplified } \\
\text { segment (bp) }\end{array}$} & \multirow{2}{*}{$\begin{array}{c}\text { Primary } \\
\text { denaturation }\end{array}$} & \multicolumn{3}{|c|}{ Amplification (35 cycles) } & \multirow{2}{*}{$\begin{array}{c}\text { Final } \\
\text { extension }\end{array}$} & \multirow[t]{2}{*}{ Reference } \\
\hline & & & & $\begin{array}{c}\text { Secondary } \\
\text { denaturation }\end{array}$ & Annealing & Extension & & \\
\hline $\operatorname{mexR}$ & $\begin{array}{l}\text { GCGCCATGGC } \\
\text { CCATAT TCAG } \\
\text { GGCATTC GCC } \\
\text { AGTAAGCGG }\end{array}$ & 637 & $\begin{array}{l}94^{\circ} \mathrm{C} \\
5 \min \end{array}$ & $\begin{array}{l}94^{\circ} \mathrm{C} \\
45 \mathrm{~s}\end{array}$ & $\begin{array}{l}57^{\circ} \mathrm{C} \\
45 \mathrm{~s}\end{array}$ & $\begin{array}{l}72^{\circ} \mathrm{C} \\
45 \mathrm{~s}\end{array}$ & $\begin{array}{c}72^{\circ} \mathrm{C} \\
10 \mathrm{~min}\end{array}$ & {$[16]$} \\
\hline
\end{tabular}

$\mathrm{PCR}=$ Polymerase chain reaction

Table-2: Multiplex PCR: Primers sequences, target genes, amplicon sizes, and cycling conditions.

\begin{tabular}{|c|c|c|c|c|c|c|c|c|}
\hline \multirow{2}{*}{$\begin{array}{l}\text { Target } \\
\text { gene }\end{array}$} & \multirow{2}{*}{$\begin{array}{l}\text { Primers } \\
\text { sequences }\end{array}$} & \multirow{2}{*}{$\begin{array}{c}\text { Amplified } \\
\text { segment (bp) }\end{array}$} & \multirow{2}{*}{$\begin{array}{c}\text { Primary } \\
\text { denaturation }\end{array}$} & \multicolumn{3}{|c|}{ Amplification (30 cycles) } & \multirow{2}{*}{$\begin{array}{c}\text { Final } \\
\text { extension }\end{array}$} & \multirow[t]{2}{*}{ Reference } \\
\hline & & & & $\begin{array}{c}\text { Secondary } \\
\text { denaturation }\end{array}$ & Annealing & Extension & & \\
\hline exos & $\begin{array}{l}\text { ССТTCССT } \\
\text { CCTTCCССC } \\
\text { CGGCGATCTGGA } \\
\text { AAAG AAATG } \\
\text { CATCCTCA } \\
\text { GGCG TACATCCT }\end{array}$ & 270 & $\begin{array}{l}95^{\circ} \mathrm{C} \\
5 \mathrm{~min}\end{array}$ & $\begin{array}{l}95^{\circ} \mathrm{C} \\
30 \mathrm{~s}\end{array}$ & $\begin{array}{l}58^{\circ} \mathrm{C} \\
30 \mathrm{~s}\end{array}$ & $\begin{array}{l}72^{\circ} \mathrm{C} \\
50 \mathrm{~s}\end{array}$ & $\begin{array}{c}72^{\circ} \mathrm{C} \\
10 \mathrm{~min}\end{array}$ & {$[17]$} \\
\hline$p c / \mathrm{H}$ & $\begin{array}{l}\text { GAAGCCAT } \\
\text { GGGCT } \\
\text { ACTTCAA } \\
\text { AGAGTGA } \\
\text { CGAGG } \\
\text { AGCGGTAG }\end{array}$ & 307 & & & & & & \\
\hline toxA & $\begin{array}{l}\text { ATGGTGTA GATC } \\
\text { GGCGACAT } \\
\text { AAGCCTTC } \\
\text { GACC } \\
\text { TCTGGAAC }\end{array}$ & 433 & & & & & & \\
\hline
\end{tabular}

$\mathrm{PCR}=$ Polymerase chain reaction 
Table-3: Prevalence of Pseudomonas aeruginosa recovered from living and slaughtered sheep and goat.

\begin{tabular}{|c|c|c|c|c|c|c|c|}
\hline \multirow[t]{2}{*}{ Groups } & \multirow[t]{2}{*}{ Type of samples } & \multicolumn{3}{|c|}{ Sheep } & \multicolumn{3}{|c|}{ Goat } \\
\hline & & $\begin{array}{c}\text { No. of } \\
\text { samples }\end{array}$ & $\begin{array}{l}\text { Positive } \\
\text { samples } \\
\text { number }\end{array}$ & $\begin{array}{c}\text { Positive } \\
\text { samples \% }\end{array}$ & $\begin{array}{c}\text { No. of } \\
\text { samples }\end{array}$ & $\begin{array}{l}\text { Positive } \\
\text { samples } \\
\text { number }\end{array}$ & $\begin{array}{c}\text { Positive } \\
\text { samples \% }\end{array}$ \\
\hline \multirow{3}{*}{$\begin{array}{l}\text { I-animals with respiratory } \\
\text { manifestation }\end{array}$} & Nasal swabs & 40 & 3 & $(7.5)$ & 22 & 2 & $(9.1)$ \\
\hline & Tracheal swabs & 40 & 2 & (5) & 22 & 0 & 0 \\
\hline & Lung tissues & 40 & 1 & $(2.5)$ & 22 & 0 & 0 \\
\hline II-animals with skin lesions & Wound and abscesses & 21 & 2 & $(9.5)$ & 16 & 1 & $(6.25)$ \\
\hline III-diarrheic animals & Fecal & 14 & 1 & $(7.1)$ & 23 & 1 & $(4.3)$ \\
\hline Total & & 155 & 9 & $(5.8)$ & 105 & 4 & $(3.8)$ \\
\hline
\end{tabular}

Table-4: Antibiotic sensitivity test of (13) Pseudomonas aeruginosa strains isolated from sheep and goat.

\begin{tabular}{lccc}
\hline Antimicrobial agents & Sensitive & & Resistant \\
\cline { 2 - 2 } & $\boldsymbol{n}(\boldsymbol{\%})$ & & $\boldsymbol{n} \mathbf{( \% )}$ \\
\hline Amikacin & $3(23.1)$ & & $10(76.9)$ \\
Ampicillin & $0(0)$ & & $13(100)$ \\
Bacitracin & $0(0)$ & $13(100)$ \\
Chloramphenicol & $2(15.4)$ & $11(84.6)$ \\
Erythromycin & $0(0)$ & $13(100)$ \\
Gentamicin & $4(30.8)$ & $9(69.2)$ \\
Streptomycin & $0(0)$ & & $13(100)$ \\
Tetracycline & $0(0)$ & $13(100)$ \\
Trimethoprirn/sulfamethoxazole & $0(0)$ & $13(100)$ \\
Tobramycin & $0(0)$ & $13(100)$ \\
Ciprofloxacin & $13(100)$ & $0(0)$ \\
Norfloxacin & $12(92.3)$ & $1(4.5)$ \\
\hline
\end{tabular}

$1 \times$ TBE buffer at room temperature using gradients of $5 \mathrm{~V} / \mathrm{cm}$. For gel analysis, $15 \mu \mathrm{l}$ of the products were loaded in each gel slot. A 100 bp DNA Ladder (Qiagen, Germany, $\mathrm{GmbH}$ ) was used to determine the fragment sizes. The gel was photographed by a gel documentation system (Alpha Innotech, Biometra) and the data were analyzed through computer software. P. aeruginosa (ATCC 27853) was used as positive controls and distilled water (Merck, Germany) was used as a negative control in all PCR reactions.

P. aeruginosa (ATCC 15442) was used as a positive control while Staphylococcus aureus (ATCC 25923) was used as a negative one.

\section{Results and Discussion}

$P$. aeruginosa is an environmental ubiquitous nonpathogenic saprophyte present in animate and inanimate media. Otherwise, in many statuses, this microorganism becomes a primary pathogen and is encountered in severe localized or generalized infections in human, animals, and birds particularly among immune-compromised hosts [19]. The organism was implicated in multiple diseases in sheep and goat; respiratory manifestation, diarrhea, skin abscess, and the severity of the condition may result in death cases [20,21].

In this study, as shown in Table-3, it was found that $P$. aeruginosa was successfully isolated from $(6 / 40)$ sheep and (2/22) goat with respiratory manifestation with an incidence of $15 \%$ and $9.1 \%$, respectively. The isolates were recovered from $3(7.5 \%)$ sheep and $2(9.1 \%)$ goat nasal swabs. Furthermore, the organism was recovered from $2(5 \%)$ tracheal swabs and $1(2.5 \%)$ lung tissue belonged only to sheep samples.

These average percentage results agreed with that formerly reported $[22,23]$ while the lower incidence was 3.6\% [24] and one necropsied goat [25]. In contrast, higher isolations were determined [26]. Two $P$. aeruginosa isolates were recovered from diarrheic sheep $1 / 14(7.1 \%)$ and goat $1 / 23(4.3 \%)$, respectively. On the other hand, the animals infected with wound and abscesses, the percentage of isolated P. aeruginosa from sheep was $2 / 21(9.5 \%)$ and goat $1 / 16(6.25 \%)$, respectively. These obtained data close to that stated by Hears et al. [27], who isolated three strains P. aeruginosa from one of the infected sheep flocks. Abd El-Rahman [28] deduced that the incidence of P. aeruginosa recovered from diarrheic sheep was higher than that obtained among specimens of other infected animals. Furthermore, current results less than that obtained by Alkeshan [29], who isolated P. aeruginosa from abscesses with an incidence (6.18\%).

The unselective use of antibiotics is potentially leading to a higher incidence of infections with resistant microorganisms such as $P$. aeruginosa, worse which may be transmitted from animal to human complicating the treatment of human diseases [30]. Regarding, the antimicrobial sensitivity agar test shown in (Table-4); it was noticed that the isolates were lack of susceptibility to many tested antimicrobial agents. The primary mechanism of the microorganism's resistance relies on its ability to shut out various agents rather than the production of antibiotic inactivating enzymes. Consequently, most of antibiotics are of limited value in the treatment of $P$. aeruginosa infection in animals [31].

The results indicated that the isolates were susceptible to both ciprofloxacin $13(100 \%)$ and norfloxacin $12(92.3 \%)$, while completely resistant to ampicillin, bacitracin, erythromycin, streptomycin, tetracycline, trimethoprim-sulfamethoxazole, and tobramycin, most of the isolates were resistant to amikacin, chloramphenicol, and gentamycin. These findings agreed with the other previous studies which illustrated that the organism is resistant to all used antibiotics except quinolones [32-35].

Assorted chromosomally encoded efflux systems and outer membrane porins have been distinguished as essential contributors to MDR phenotype 


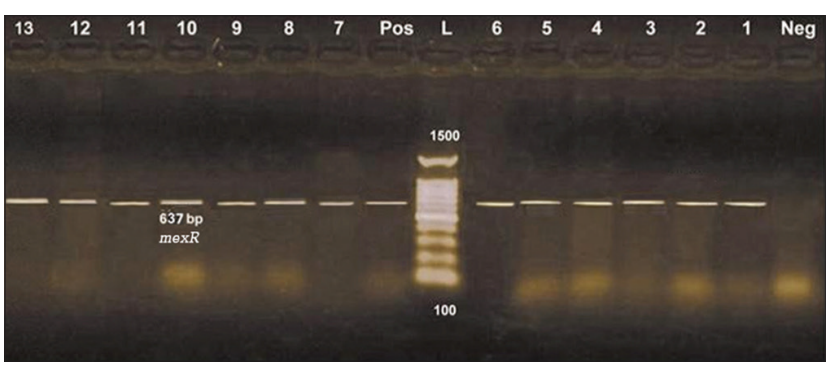

Figure-1: Uniplex polymerase chain reaction detection of antibiotic-resistant mexR operon in Pseudomonas aeruginosa isolates showing: L: 100 bp DNA ladder. Lanes 1-13: P. aeruginosa isolates. Lane Pos.: Positive control; amplification of $637 \mathrm{bp}$ represented mexR. Lane Neg.: Negative control.

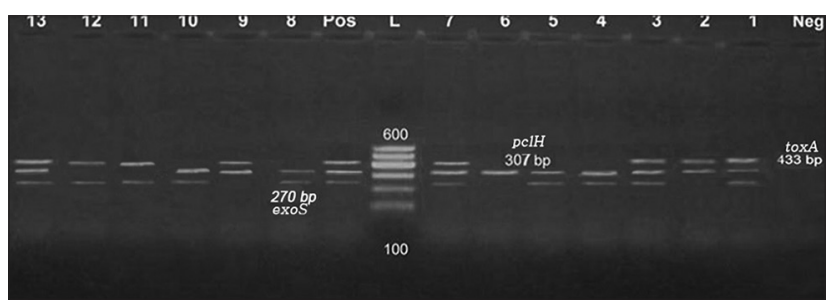

Figure-2: Multiplex polymerase chain reaction detection of virulence genes in Pseudomonas aeruginosa isolates showing: L: 100 bp DNA ladder. Lanes 1-13: $P$. aeruginosa isolates. Lane Pos.: Positive control; amplification of $270 \mathrm{bp}$ represented exoS, $307 \mathrm{bp}$ represented $\mathrm{p} / \mathrm{cH}$, and $433 \mathrm{bp}$ represented toxA. Lane Neg.: Negative control.

resistance. The MexAB-OprM is the only pump which is expressed at a level enough to allow intrinsic MDR in wild type $P$. aeruginosa strains. Mutations in mexR cause over-expression of MexAB-OprM efflux pump [36]. It is obvious in our study as shown in Figure-1; that all isolates exhibited the amplification of $637 \mathrm{bp}$ which represent the mexR operon. The emergence of MDR P. aeruginosa is turning out a challenging issue in infection control schemes.

Figure-2 shows multiplex PCR detection of virulence genes in $P$. aeruginosa isolates $P$. aeruginosa is considered a potent opportunistic pathogen and this is contributed to its ability to produce arrays of virulence agents which aid the organism to attach, penetrate, disseminate, and inhibit phagocytosis, and chemotaxis [37]. The data obtained from Figure-2 revealed the multiplex PCR reaction of three genes amplification; plc $\mathrm{H}$ (307bp), exoS (270bp), and tox $\mathrm{A}$ (433 bp) which responsible for expression of cytotoxins, phospholipase, and enterotoxins as 12 (92.3\%), $10(76.9 \%)$, and $8(61.5 \%)$, respectively. These results drew near the other previous investigations [38-42].

\section{Conclusion}

P. aeruginosa could be implicated in sheep and goat infections, and the isolates showed high resistance to commonly used antibiotics as well as having numerous agents of virulence. A strict antibiotic policy and establishment of infection control programs will help to lower the incidence of resistance in $P$. aeruginosa.

\section{Authors' Contributions}

ASH and AND supervised the experiment. AMA and EAE shared in the collection of the samples, AND and HAA did the isolation and identification of microorganism. EAE performed the antibiotic susceptibility assay. HAA and AMA performed PCR. ASH and AND prepared and reviewed the manuscript. All authors read and approved the final manuscript.

\section{Acknowledgments}

The authors are thankful to National Research Centre, Egypt for providing necessary facilities for this study. The authors would like to thank Editage (www.editage.com) for English language editing. The authors did not receive any fund for this study.

\section{Competing Interests}

The authors declare that they have no competing interests.

\section{Publisher's Note}

Veterinary World remains neutral with regard to jurisdictional claims in published institutional affiliation.

\section{References}

1. Yang, J., Zhao, H.L. Ran, L.Y., Li, C.Y., Zhang, X.Y., Su, H.N., Shi, M., Zhou, B.C., Chen, X.L. and Zhang, Y.Z. (2015) Mechanistic insights into elastin degradation by pseudolysin, the major virulence factor of the opportunistic pathogen Pseudomonas aeruginosa. Sci. Rep., 23(5): 9936.

2. Bird, V.Y., Chastain-Gross, R., Sutkowski, R., Bird, V.G., Vyas, P. and Joseph, R. (2017) Pseudomonas aeruginosa as an etiologic agent of nephrolithiasis in deep water divers. J. Endourol. Case Rep., 3(1): 4-6.

3. Bangar, Y.C., Pachpute, S.T. and Nimase, R.G. (2016) The survival analysis of the potential risk factors affecting lamb mortality in Deccani sheep. J. Dairy Vet. Anim. Res., 4(2): 266-270.

4. Wright, E.A., Di Lorenzo, V., Trappetti, C., Liciardi, M., Orru, G., Viti, C., Bronowski, C., Hall, A.J., Darby, A.C., Oggioni, M.R. and Winstanley, C. (2015) Divergence of a strain of Pseudomonas aeruginosa during an outbreak of ovine mastitis. Vet. Microbiol., 175(1): 105-113.

5. Chigerwe, M., Mavangira, V., Byrne, B.A. and Angelos, J.A. (2017) Antibiotic resistance patterns of bacteria isolated from indwelling foley catheters following tube cystostomy in goats with obstructive urolithiasis. J. Vet. Diagn. Invest., 29(3): 316-320.

6. Hwang, I.Y., Koh, E., Wong, A., March, J.C., Bentley, W.E., Lee, Y.S. and Chang, M.W. (2017) Engineered probiotic Escherichia coli can eliminate and prevent Pseudomonas aeruginosa gut infection in animal models. Nat. Commun., 11(8): 15028

7. Fong, S.A., Drilling, A.J., Ooi, M.L., Paramasivan, S., Finnie, J.W., Morales, S., Psaltis, A.J., Vreugde, S. and Wormald, P.J. (2018) Safety and efficacy of a bacteriophage cocktail in an in vivo model of Pseudomonas aeruginosa sinusitis. Transl. Res., 206(4): 41-56.

8. Rasooli, A., Nouri, M., Esmaeilzadeh, S., Ghadiri, A., Gharibi, D., Koupaei, M.J. and Moazeni, M. (2018) Occurrence of purulent mandibular and maxillary osteomyelitis associated with Pseudomonas aeruginosa in a sheep flock in south-west of Iran. Iran J. Vet. Res., 19(2): 133-136.

9. Mccarty, S.M., Cochrane, C.A., Clegg, P.D. and Percival, S.L. (2012) The role of endogenous and exogenous enzymes in chronic wounds: A focus on the implications 
of aberrant levels of both host and bacterial proteases in wound healing. Wound Repair Regen., 20(2): 125.

10. Tayabali, A.F., Gordon, C. and Kathy, C.N. (2015) Virulence attributes and host response assays for determining pathogenic potential of Pseudomonas strains used in biotechnology. PLoS One, 10(11): e0143604.

11. Hu, P., Chen, J., Chen, Y., Zhou, T., Xu, X. and Pei, X. (2017) Molecular epidemiology, resistance, and virulence properties of Pseudomonas aeruginosa cross-colonization clonal isolates in the non-outbreak setting. Infect. Genet. Evol., 55(11): 288-296.

12. Briers, Y., Walmagh, M., Grymonprez, B., Biebl, M., Pirnay, J.P., Defraine, V., Michiels, J., Cenens, W., Aertsen, A., Miller, S. and Lavigne, R. (2014) Art-175 is a highly efficient antibacterial against multidrug-resistant strains and persisters of Pseudomonas aeruginosa. Antimicrob. Agents Chemother., 58(7): 3774-3784.

13. Xu, Z.Q., Flavin, M.T. and Flavin, J. (2014) Combating multidrug-resistant Gram-negative bacterial infections. Expert Opin. Invest. Drugs, 23(2): 163-182.

14. Quinn, P.J., Markyl, B.K., Carter, M.E., Donnelly, W.J. and Leonard, F.C. (2002) Veterinary Microbiology anal Microbial Disease. Blackwell, United Kingdom.

15. Clinical Laboratory Standards Institute. (2015) Performance Standards for Antimicrobial Disk Susceptibility Tests; Approved Standards. $12^{\text {th }}$ ed. Clinical Laboratory Standards Institute, USA, pM02-A12.

16. Magiorakos, A.P., Srinivasan, A., Carey, R.B., Carmeli, Y., Harbarth, S., Hindler, J.F., Kahlmeter, G. and Monnet, D.L. (2012) Multidrug-resistant, extensively drug-resistant and pandrug-resistant bacteria: An international expert proposal for interim standard definitions for acquired resistance. Clin. Microbiol. Infect., 18(3): 268-281.

17. Odumosu, B.T., Adeniyi, B.A. and Chandra, R. (2016) First detection of OXA-10 extended-spectrum beta-lactamases and the occurrence of mex $\mathrm{R}$ and $n f x \mathrm{~B}$ in clinical isolates of Pseudomonas aeruginosa from Nigeria. Chemotherapy, 61(2): 87-92.

18. Hui, S., Quoclinh, T., Wentao, X., Baiqiang, Z.H., Yunbo, L. and Kunlun, H. (2012) A universal primer multiplex PCR method for typing of toxinogenic Pseudomonas aeruginosa. Appl. Microbiol. Biotechnol., 95(6): 1579-1587.

19. Gellatly, H., Gellatly, S.L. and Hancock, R.E.W. (2013) Pseudomonas aeruginosa: New insights into pathogenesis and host defenses. Pathog. Dis., 67(3): 159-173.

20. Cassirer, E.F. and Sinclair, A.R.E. (2007) Dynamics of pneumonia in a bighorn sheep meta population. J. Wildl. Manage., 71(4): 1080-1088.

21. Khaled, B.H. (2011) Prevalence and etiology of abscess disease of sheep and goats at Qassim Region, Saudi Arabia. Vet. World, 4(11): 495-499.

22. Almeida, P.F., Alves, F.S.F., Santos, L.F. and Rosa, J.S. (1986) Survey on bacterial agents associated with respiratory diseases of goats in North-Eastern Brazil. Rev. Microbiol., 17(3): 213-215.

23. Pasic, S. and Popvic, M. (1988) Study of ovine Mycoplasma in Bosnia and Herzegovina. Mycoplasma and bacteria in the pneumonic lungs of sheep. Vet. Yugoslavia, 37(1): 35-39.

24. Baysal, T. and Guler, L. (1992) Isolation of bacteria from enzootic pneumonia in lambs and kids in the Kenya region. Veterinarium, 3(1): 1-5.

25. Shiferaw, G., Tariku, S., Ayelet, G. and Abebe, Z. (2006) Contagious caprine pleuropneumonia and Mannheimia haemolytica-associated acute respiratory disease of goats and sheep in Afar Region, Ethiopia. Rev. Sci. Tech., 25(3): 1153-1163.

26. Mishra, K.C. (1992) Antimicrobial sensitivity of bacteria isolated from respiratory tract infection of goats in Sikkim. Ind. J. Anim. Sci., 26(7): 635-636.
27. Hears, A., Dominguez, L., Lopez, J., Hears, A.L. and Garayzabal, J. (1999) Outbreak of ovine mastitis associated with $P$. aeruginosa infection. Vet. Rec., 145(4): 111-112.

28. Abd El-Rahman, W.M. (2004) Further Studies on Strains Isolated from Broiler Chickens. Ph.D. Thesis (Microbiology). Faculty of Veterinary Medicine, Cairo University, Egypt.

29. Alkeshan, Y.M., Alharbi, S., Alrehaili, F., Almutiri, J., Althobity, M. and Alotaibi, N. (2015) Antimicrobial resistance pattern of Pseudomonas aeruginosa in regional tertiary care hospitals of Saudi Arabia. IOSR J. Nurs. Health Sci., 5(2): 54-62.

30. Wiedmann, M., Weilmeier, D., Dineen, S.S., Ralyea, R. and Boor, K.J. (2000) Molecular and phenotypic characterization of Pseudomonas spp. isolated from milk. Appl. Environ. Microbiol., 66(5): 2085-2095.

31. Bhullar, K., Waglechner, N., Pawlowski, A., Koteva, K., Banks, E.D., Johnston, M.D., Barton, H.A. and Wright, G.D. (2012) Antibiotic resistance is prevalent in an isolated cave microbiome. PLoS One, 7(4): e34953.

32. Siew, M.L., Ganeswrei, R., Ampalam, P. and Kek, H.C. (2019) Antimicrobial susceptibility and virulence genes of clinical and environmental isolates of Pseudomonas aeruginosa. PeerJ, 7: e6217.

33. Enas, G., Samah, A. and Magdy, K. (2010) Prevalence of multi-drug resistant Pseudomonas spp. and Acinetobacter spp. causing nosocomial infection in intensive care unit (ICU) of National Liver Institute. Egypt. J. Med. Microbiol., 19(1):1.

34. Sahar, M.H. (2012) Comparison of Microbial Isolates from External Ear Canal of Sheep and their Susceptibility to Antibiotics. $11^{\text {th }}$ Proceeding Veterinary Science Conference. p41-48.

35. Hannah, J., Kathryn, S.L. and Martin, W. (2018) Ciprofloxacin binding to GyrA causes global changes in the proteome of Pseudomonas aeruginosa. FEMS Microbiol. Lett., 365(13): 134.

36. Thanyaluck, S., Potjanee, S., Sasitorn, C., Boonek, Y., Channarong, S., Varomyalin, T. and Supayang, P.V. (2017) Conessine as a novel inhibitor of multidrug efflux pump systems in Pseudomonas aeruginosa. BMC Complement. Altern. Med., 17(1): 405.

37. Habibi, A. and Honarmand, R (2015) Profile of virulence factors in the multi-drug resistant Pseudomonas aeruginosa strains of human urinary tract infections (UTI). Iran Red. Crescent Med. J., 17(12): e26095.

38. Mitov, I., Strateva, T. and Markova, B. (2010) Prevalence of virulence genes among Bulgarian nosocomial and cystic fibrosis isolates of Pseudomonas aeruginosa. Braz. J. Microbiol., 41(3): 588-595.

39. Heidary, Z., Bandani, E., Eftekhary, M. and Jafari, A.A. (2016) Virulence genes profile of multidrug-resistant Pseudomonas aeruginosa isolated from Iranian children with UTIs. Acta Med. Iran., 54(3): 201-210.

40. Khosravi, A.D., Shafie, F., Montazeri, E.A. and Rostami, S. (2016) The frequency of genes encoding exotoxin A and exoenzyme $\mathrm{S}$ in Pseudomonas aeruginosa strains isolated from burn patients. Burns, 42(5): 1116-1120.

41. Pobiega, M., Maciag, J., Pomorska-Wesolowska, M., Chmielarczyk, A., Romaniszyn, D., Ziolkowski, G., Heczko, P.B., Wojkowska-Mach, J. and Bulanda, M (2016) Urinary tract infections caused by Pseudomonas aeruginosa among children in Southern Poland: Virulence factors and antibiotic resistance. J. Pediatr. Urol., 12(1): 36.e1-6.

42. Badamchi, A., Masoumi, H., Javadinia, S., Asgarian, R. and Tabatabaee, A. (2017) Molecular detection of six virulence genes in Pseudomonas aeruginosa isolates detected in children with urinary tract infection. Microb. Pathog., 107(6): 44-47. 